\title{
Assessment of coronary heart diseases in diabetics in al-Madinah al-Munawarah [Retraction]
}

al-Nozha O, Mojadadi M, Mosaad M, El-Bab MF. Assessment of coronary heart diseases in diabetics in al-Madinah al-Munawarah. International Journal of General Medicine. 2012;5:143-149.

Authors Omar al-Nozha and Moaz Mojadadi were not aware that their names had been used and state that the signatures on the approval document received by the journal are not theirs.

\section{Publish your work in this journal}

The International Journal of General Medicine is an international, peer-reviewed open-access journal that focuses on general and internal medicine, pathogenesis, epidemiology, diagnosis, monitoring and treatment protocols. The journal is characterized by the rapid reporting of reviews, original research and clinical studies across all disease areas.
The manuscript management system is completely online and includes a very quick and fair peer-review system, which is all easy to use. Visit http://www.dovepress.com/testimonials.php to read real quotes from published authors. 